\title{
Growth factor modulation of p53-mediated growth arrest versus apoptosis
}

\author{
Christine E. Canman, ${ }^{1}$ Tona M. Gilmer, ${ }^{2}$ Shelagh B. Coutts, ${ }^{1}$ and Michael B. Kastan ${ }^{1,3}$ \\ ${ }^{1}$ The Johns Hopkins Oncology Center, Baltimore, Maryland 21205 USA; \\ ${ }^{2}$ Glaxo Research Institute, Research Triangle Park, North Carolina 27709 USA
}

Irradiation of mammalian cells can cause cell cycle perturbations and apoptotic cell death. We have investigated the modulation of these physiologic end points by growth factor stimulation: irradiation of a murine hematopoietic cell line in the presence of interlekin-3 (IL-3) induces $G_{1}$ arrest, and irradiation in the absence of IL-3 results in rapid apoptotic cell death. Both of these end points are dependent on p53. Transient removal of IL-3 at the time of irradiation results in decreased clonogenic survival of irradiated cells. The removal of IL-3 results in a failure of the irradiated cells to arrest at the $G_{1}$ checkpoint, despite induction of p53 and p21 WAF1/CIP1, and then the cells enter S-phase where they undergo apoptosis. There are no cytokine-related changes in Bcl-2, Bax, or Bcl-x protein levels that could account for the modulation of $\mathbf{G}_{1}$ arrest versus apoptosis by growth factors. In contrast, rapid p53-independent alterations of basal levels of gadd45 and $\mathrm{P}_{21}{ }^{\mathrm{WAF} 1 / C I P 1}$ expression are linked to IL-3 withdrawal, suggesting a potential mechanism for this modulation. Constitutive activation of cytokine-like pathways with induced expression of v-Src or activated c-Raf inhibits the radiation-induced apoptosis and the alterations in $\mathbf{2 2 1}{ }^{\text {WAF1/CIP1 }}$ and gadd45 expression. These observations suggest additional molecular mechanisms that can contribute to the development of radioresistance and resistance to apoptosis during tumorigenesis and provide an explanation for the observed lack of p53 mutations in some tumor types. In addition, these data suggest that oncogenic changes occurring during multistep tumorigenesis could be classified as those that either enhance or decrease apoptosis tendencies.

[Key Words: IL-3; $221^{\mathrm{WAF} 1 / \mathrm{CIP} 1}$; gadd45; src; raf]

Received December 21, 1994; revised version accepted January 31, 1995.

Exposure of cells to DNA-damaging agents can result in (1) timely repair of the damage and maintenance of genetic fidelity in daughter cells, (2) cell death, or (3) the development of heritable genetic changes in viable daughter cells by the replication of damaged DNA or the segregation of damaged chromosomes before repair. The latter outcome could generate the genetic changes that contribute to the development of a malignant phenotype. Therefore, the gene products that control timely repair and appropriate cell death after DNA damage are likely to be critical determinants of neoplastic evolution. In addition, as most antineoplastic agents are DNA-damaging agents, these same gene products probably influence response and cure rates during the treatment of human tumors.

The tumor suppressor gene product p53 is a critical mediator of cellular responses to DNA damage in mammalian cells. Both $\mathrm{G}_{1}$ cell cycle arrest (Kastan et al. 1991, 1992; Kuerbitz et al., 1992) and apoptotic cell death (Clarke et al. 1993; Lotem and Sachs 1993; Lowe et al. 1993) after ionizing irradiation (IR) have been shown to be dependent on normal p53 function. Cellular irradia-

${ }^{3}$ Corresponding author. tion initiates a signal transduction pathway that results in a post-transcriptional increase in the levels of p53 protein and subsequently p53-dependent increases in the transcription of several gene products, including gadd45 [growth arrest and DNA damage (-inducible)], p21 WAF1 TCIP1 and Mdm2 (Kastan et al. 1992; Barak et al. 1993; El-Deiry et al. 1993, 1994; Wu et al. 1993; Chen et al. 1994; Dulic et al. 1994; Slebos et al. 1994; Zhan et al. 1994a). It is suspected, but not yet proven, that the former two gene products contribute to the growth arrest or apoptosis, or both, that occurs after IR (El-Deiry et al. 1993, 1994; Harper et al. 1993; Dulic et al. 1994; Slebos et al. 1994; Smith et al. 1994; Zhan et al. 1994b).

Whether IR induces a $G_{1}$ cell cycle arrest /e.g., fibroblasts) or rapid programmed cell death (e.g., lymphoid cells) appears to be cell-type dependent (Kastan et al. 1992; Clarke et al. 1993; Lowe et al. 1993; Slichenmyer et al. 1993); however, the determinants of these two disparate cellular outcomes after irradiation have not yet been clarified. Thus far, the role of p53 in mediating apoptosis has been studied most effectively in either primary thymocytes from genetically manipulated mice (Clarke et al. 1993; Lotem and Sachs 1993; Lowe et al. 1993) (which are not very amenable to further genetic manipulation or to clonogenic survival studies|, systems 
in which an overexpressed temperature-sensitive p53 allele has been introduced stably into cells (YonishRouach et al. 1991; Wu and Levine 1994), or in cells where expression of adenovirus E1a drives the cell down a pathway resulting in p53-dependent apoptosis (Debbas and White 1993; Lowe and Ruley 1993; Lowe et al. 1994). Because Ela overexpression by itself is cytotoxic, however, these latter systems are limited by the additional requirements for the use of either an overexpressed, temperature-sensitive mutant p53 (Debbas and White 1993), coexpression of a gene product that blocks apoptosis, such as adenovirus E1b19 or Bcl-2 (Debbas and White 1993), or the introduction of another genetic change [such as Ras mutation and overexpression (Lowe et al. 1994) l, all of which allow the cell to tolerate Ela expression.

We chose to attempt the study of this "decision fork" in a cell system in which the introduction of exogenous genes was not required to generate either the apoptosis or $G_{1}$ arrest phenotype, in which the p53 alleles were endogenous, in which alterations in clonogenic survival could be assessed, and in which physiologic events that normally induce p53-dependent responses were involved. Baf-3 is a nonmalignant, bone marrow-derived, interleukin 3 (IL-3)-dependent murine lymphoid lineage cell line (Palacios and Steinmetz 1985). It has been demonstrated previously that exposure of Baf-3 cells to IR results in rapid apoptosis if IL-3 has been withdrawn, whereas no apoptosis after IR is obvious in the presence of IL-3 (Collins et al. 1992; El-Deiry et al. 1994). We confirmed these initial observations and went on to use this cell system to investigate the molecular mediators of IR-induced apoptosis. In the presence of IL-3, Baf-3 cells arrest transiently in both the $G_{1}$ and $G_{2} / M$ phases of the cell cycle after IR, and the $G_{1}$ arrest is dependent on p53 function. In contrast, withdrawal of IL-3 at the time of irradiation results in a failure of the $G_{1}$ arrest checkpoint and rapid p53-dependent apoptotic cell death. Clonogenic studies demonstrate that the presence of growth factor at the time of IR provides a survival signal for the irradiated cells. Thus, this cell system offers an opportunity to evaluate what growth factor-modulated gene products affect the outcome of the cell after DNA damage induction of p53. Rapid decreases in the levels of $\mathrm{p} 21^{\mathrm{WAF} 1 / \mathrm{CIP} 1}$ and rapid increases in gadd45 expression associated with growth factor withdrawal provide suggestive models for mechanisms involved in growth factor alteration of p53-dependent $G_{1}$ arrest versus apoptosis. Overexpression of oncogenic kinases, whose normal counterparts are involved in growth factor signaling, similarly inhibits the apoptotic end point and suggests yet another mechanism for generation of tumor cell resistance to antineoplastic therapies.

\section{Results}

Growth factor modulation of $G_{1}$ arrest vs. apoptosis after irradiation

Baf- 3 cells are murine bone marrow-derived cells with lymphoid surface markers and are dependent on IL-3 for their growth in culture (Palacios and Steinmetz 1985). In addition, it has been shown that IL-3 inhibits the onset of apoptotic cell death after exposure of Baf-3 cells to DNA-damaging agents, such as IR, etoposide, and cisplatin (Collins et al. 1992). The mechanism by which this protection from apoptosis occurs has not yet been elucidated. Recently we confirmed that Baf- 3 cells exposed to IR in the absence of IL-3 rapidly undergo apoptotic cell death with classic DNA fragmentation into nucleosomal-sized DNA ladders and further demonstrated that Baf-3 cells irradiated in the presence of IL-3 exhibit cell cycle arrests in both the $G_{1}$ and $G_{2} / M$ phases of the cell cycle while failing to exhibit DNA ladders (El-Deiry et al. 1994). Two hours after IR, p53 protein levels increased whether apoptosis (-IL-3) or cell cycle arrest (+IL-3) was the outcome.

We chose to use this system to investigate the determinants of cellular outcome after p 53 induction by IR. Cell cycle arrest and apoptotic cell death were analyzed simultaneously by flow cytometry using propidium iodide staining to assess cell cycle stage and in situ labeling of DNA fragmented ends with terminal deoxynucleotide transferase ( $\mathrm{Tdt}$ )-incorporated biotinylated nucleotides to assess apoptosis (Gorczyca et al. 1993). Exposure of Baf-3 cells to 4 Gy of IR ( $1 \mathrm{~Gy}=100$ rads) in the presence of IL-3 resulted in cell cycle arrests in both $G_{1}$ and $G_{2} / M$ phases with maximum depletion of S-phase cells at $\sim 8 \mathrm{hr}$ after IR, and recovery of the cell population to a relatively normal cell cycle distribution by $22 \mathrm{hr}$ after IR (Fig, 1A, row 2). No $\mathrm{Tdt}^{+}$/apoptotic cells were seen in these cells irradiated in the presence of IL-3. In contrast, $\mathrm{Tdt}^{+} /$apoptotic cells began to appear in $<4 \mathrm{hr}$ when Baf-3 cells were irradiated in the absence of IL-3, and by $8 \mathrm{hr}$, the vast majority of cells were $\mathrm{Tdt}^{+}$ (Fig. 1A, row 4). The time course of the appearance of apoptotic cells resulting from growth factor withdrawal alone was much slower with $\mathrm{Tdt}^{+}$cells predominantly appearing between 12 and $24 \mathrm{hr}$ after growth factor withdrawal (Fig. 1A, row 3).

The cell cycle stage-specific appearance of $\mathrm{Tdt}^{+}$cells in Baf-3 cells irradiated in the absence of IL-3 was remarkably different than that seen with growth factor withdrawal alone. After IL-3 withdrawal alone, the cells appeared to continue to progress through the cell cycle until they began to accumulate in $G_{1}$ and then exhibit DNA fragmentation. Irradiated cells appeared to progress from $G_{1}$ into S-phase and it was in S-phase that cells first began to exhibit DNA fragmentation (Fig. 1A, row 4). Thus, in contrast to the $G_{1}$ arrest observed in cells irradiated in the presence of IL-3, cells irradiated in the absence of growth factor failed to arrest in $G_{1}$, entered into S-phase, and underwent apoptotic cell death. Evaluation of the $G_{1} / S$ ratio (which should increase in cells exhibiting $G_{1}$ arrest) over time after irradiation demonstrates quantitatively the presence of the $G_{1}$ arrest in cells irradiated with IL-3 and its absence in cells irradiated without IL-3 (Fig. 1B). These observations suggest that despite induction of $\mathrm{p} 53$, Baf- 3 cells irradiated in the absence of IL-3 fail to arrest at the typical p53-dependent checkpoint in $G_{1}$ and undergo rapid apoptotic cell death. 
Figure 1. The presence or absence of growth factor modulates whether Baf-3 cells undergo $\mathrm{G}_{1}$ arrest or apoptosis after IR. (A) Baf-3 cells were mock-irradiated or irradiated with $4 \mathrm{~Gy}$ of IR either in the presence or absence of 30 $\mathrm{U} / \mathrm{ml}$ of recombinant murine IL-3. Cells were harvested 4, 6, 8, 10, and $22 \mathrm{hr}$ after irradiation and subjected to the Tdt/PI assay for apoptosis as described in Materials and methods. Propidium iodide staining evaluates cellular DNA content, and biot-dUTP incorporation represents the extent of fluorosceinated avidin binding to biotinylated dUTP-labeled DNA fragments labeled at apoptotic DNA ends by terminal transferase. Discrimination of the various cell cycle stages and apoptotic cells is indicated in the top left histogram for orientation. $(B)$ The number of cells containing $G_{1}$ and S-phase content of DNA from the experiment presented in $A$ were quantitated. Data comparing cells irradiated in the presence or absence of IL-3 are presented and expressed as the $G_{1} / S$ ratio. $(C)$ Cells were treated as in $A$, harvested, and lysed in Laemmli sample buffer at $30-\mathrm{min}$ intervals after irradiation for $\leqslant 3 \mathrm{hr}$ and at $6 \mathrm{hr}$. Lysates were then immunoblotted for p53 protein. Each lane contains lysate corresponding to equivalent cell number. Equal loading was confirmed by fast green staining.
A
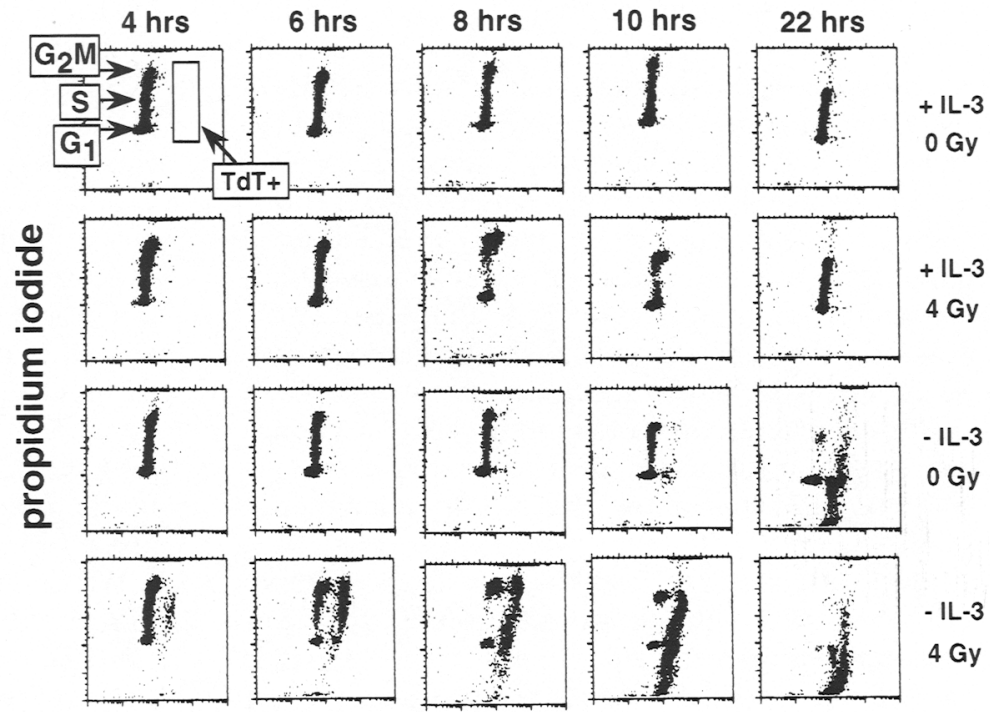

- IL-3

4 Gy

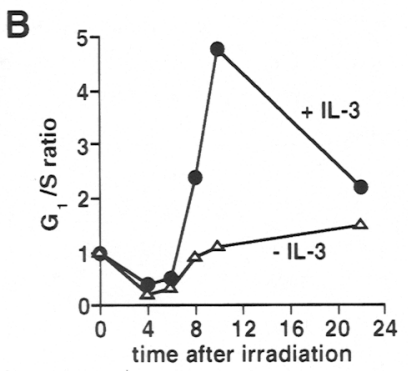

C

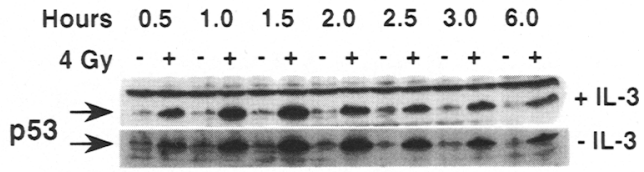

To determine whether differences in the length or extent of p53 induction after IR could account for whether an irradiated cell underwent $G_{1}$ arrest or apoptosis and whether p53 induction may be involved in apoptosis initiated by IL- 3 withdrawal alone, a detailed time course was performed measuring p 53 protein levels by immunoblot analysis. After IR, p53 protein levels increased rapidly, peaking by $1.5 \mathrm{hr}$, and then decreased rapidly toward basal levels by $3 \mathrm{hr}$ in Baf-3 cells cultured either in the presence or absence of IL-3 (Fig. 1C). p53 protein levels did not appear to increase above basal levels in cells that were grown in the absence of IL-3 alone, suggesting that p53 does not participate directly in the initiation of this apoptotic pathway. Three independent experiments indicated that neither the extent nor the length of p53 induction differs in cells undergoing $\mathrm{G}_{1}$ arrest compared with those undergoing apoptosis after IR.

p53 is required for both $I R$-induced $G_{1}$ arrest and apoptosis in Baf-3 cells

To establish the dependency of both pathways on p53, Baf-3 cells were transfected stably with the high-risk human papillomavirus (HPV) E6 gene after selection for the coexpression of neomycin resistance. E6 promotes the degradation of endogenous p53 by a ubiquitin-mediated pathway (Scheffner et al. 1990) and has been shown to abrogate both $\mathrm{p} 53$ induction and $\mathrm{G}_{1}$ arrest in irradiated cells (Kessis et al. 1993; Demers et al. 1994; Dulic et al. 1994). Several stable clones of Baf-3 cells expressing E6 were isolated based on the absence of $\mathrm{p} 53$ induction after IR. Figure 2A demonstrates the absence of p53 induction in one such E6-expressing Baf-3 clone, E6.18, after IR in the presence or absence of IL-3. Pooled Baf-3 cells expressing neomycin resistance alone induced p53 to an equivalent extent as parental cells. Both IR-induced $G_{1}$ arrest and apoptosis were abrogated in E6.18 cells as indicated by the persistence of cells in $S$, low $G_{1} / S$ ratios as compared with neomycin control cells, and the absence of biotinylated dUTP-labeled cells $8 \mathrm{hr}$ after exposure to IR (Fig. 2B). Similarly, overexpression of a mutant p53 transgene inhibited IR-induced apoptosis (data not shown). The $G_{2}$ arrest pathway is still intact in irradiated E6.18 cells consistent with previous observations demonstrating that cells lacking wild-type p53 function only lose the $\mathrm{G}_{1}$ checkpoint after exposure to IR (Kastan et al. 1991). Interestingly, loss of p53 function through expression of E6 appeared to delay IL-3 withdrawal-induced apoptosis by $24-48 \mathrm{hr}$ suggesting that $\mathrm{p} 53$ affects this apoptotic pathway, but, in contrast to IR-induced apoptosis, is not required (data not shown). 


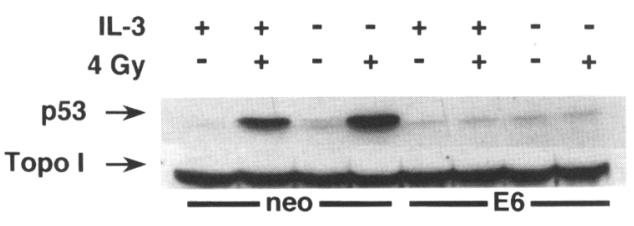

B

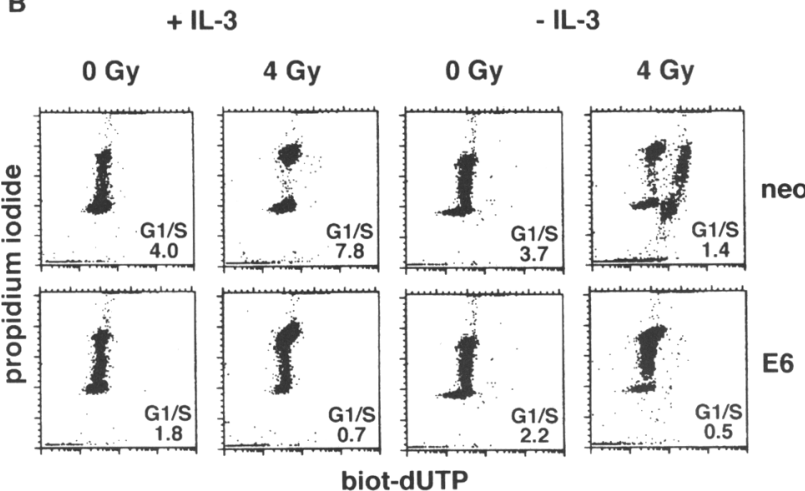

Figure 2. Abrogation of both IR-induced apoptosis and $\mathrm{G}_{1}$ arrest through stable expression of the HPV-16 E6 protein. $(A) \mathrm{A}$ polyclonal population of cells expressing neomycin resistance alone (neo) or clone E6.18 (E6) was assayed for p53 protein levels by immunoblot analysis $1.5 \mathrm{hr}$ after exposure to $4 \mathrm{~Gy}$ of IR either in the absence or presence of IL-3, or $(B)$ for the abilility of IR to induce $G_{1}$ arrest in the presence of IL-3 or apoptosis in the absence of IL-3 by FACScan analysis as in Fig. 1A. Cells were harvested $8 \mathrm{hr}$ after irradiation. The source of IL-3 for these experiments was $10 \%$ WEHI 3B-conditioned media.

\section{Transient removal of $I L-3$ sensitizes Baf-3 cells to irradiation-induced cell death}

Although abrogation of the $G_{1}$ checkpoint through loss of p53 function does not appear to influence the survival of many cell types after IR (Slichenmyer et al. 1993), loss of p53-mediated apoptosis in response to irradiation has been demonstrated to render lymphoid cells (e.g., murine thymocytes) resistant to cell death (Clarke et al. 1993; Lotem and Sachs 1993; Lowe et al. 1993). Because of the limited ability to culture cells, such as murine thymocytes, clonogenic survival could not be assessed in these studies; therefore, the extent of survival after irradiation was determined by short-term assays such as membrane permeability. To determine the long-term effect of the presence or absence of rapid p53-mediated apoptosis on cell survival after IR, clonogenic survival was assessed in Baf-3 cells irradiated both in the presence and absence of IL-3. Transient removal of IL-3 for $6 \mathrm{hr}$ decreased the surviving fraction of cells by approximately twofold after exposure to various doses of IR (Fig. 3). The importance of clonogenic assays for such assessment is illustrated by the fact that although the presence of growth factor during IR inhibits detectable apoptosis (see Fig. 1), and membrane permeability assays at early time points would support absolute radioresistance /Collins et al. 1992), clonogenic survival assays reveal a measurable inhibition of colony formation after IR.
Levels of apoptosis-influencing gene products are not altered during IR-induced apoptosis

Apoptosis-protecting gene products, such as Bcl-2 (Nunez et al. 1990; Otani et al. 1993) and Bcl- $x_{L}$ (Boise et al. 1993), have been linked to growth factor-related pathways. Withdrawal of growth factor has been associated with down-regulation of Bcl-2 expression (Nunez et al. 1990; Otani et al. 1993) and it has been hypothesized that this is responsible for the increased tendency of these cells to undergo apoptosis under these conditions. Furthermore, p53 not only has been demonstrated to down-regulate Bcl-2 levels but also to induce the levels of Bax, an apoptosis-promoting protein (Miyashita et al. 1994; Selvakumaran et al. 1994). Therefore, it is conceivable that the combined effect of irradiation in the absence of IL-3 may be to increase the susceptibility of Baf-3 cells to apoptosis by down-regulation of Bcl-2 or $\mathrm{Bcl}-\mathrm{x}_{\mathrm{L}}$ or the up-regulation of Bax protein levels. Neither Bcl-2 nor Bax protein levels changed $\leqslant 24$ hr after IL-3 withdrawal (Fig. 4). Bcl- $\mathrm{x}_{\mathrm{L}}$ levels do appear to be downregulated by $24 \mathrm{hr}$; however, during the period of extensive apoptosis induced by IR in the absence of IL-3 (i.e., 3,6 , and $9 \mathrm{hr}$ ), levels of Bcl- $\mathrm{x}_{\mathrm{L}}$ do not appear to decrease. We do note that there may be a small increase in Bax protein levels in irradiated cells both in the presence and absence of IL-3, but whether these changes are physiologically significant is difficult to interpret. Therefore, whether IR induction of $p 53$ results in $\mathrm{G}_{1}$ arrest or apoptosis does not appear to be determined by alterations in the expression of $\mathrm{Bcl}-2, \mathrm{Bcl}-\mathrm{x}_{\mathrm{L}}$, or Bax. However, these studies do not eliminate the possibility that IL-3 withdrawal may influence the activities of these proteins through some other mechanism, thereby increasing the susceptibility of Baf- 3 cells to IR-induced apoptosis.

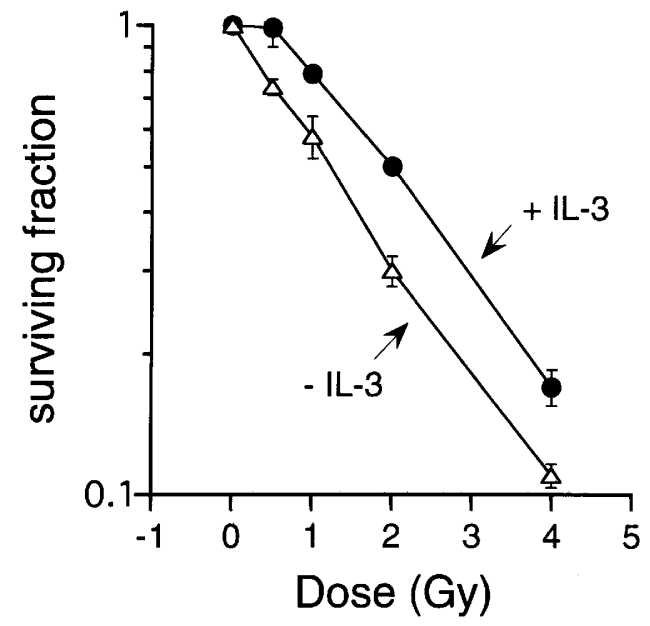

Figure 3. Transient removal of growth factor increases irradiation-induced cell death assessed by clonogenic survival. Baf-3 cells were exposed to a range of doses of IR either in the presence or absence of WEHI 3B-conditioned media and incubated for $6 \mathrm{hr}$. Cells were then harvested, counted, and assayed for colony formation. 


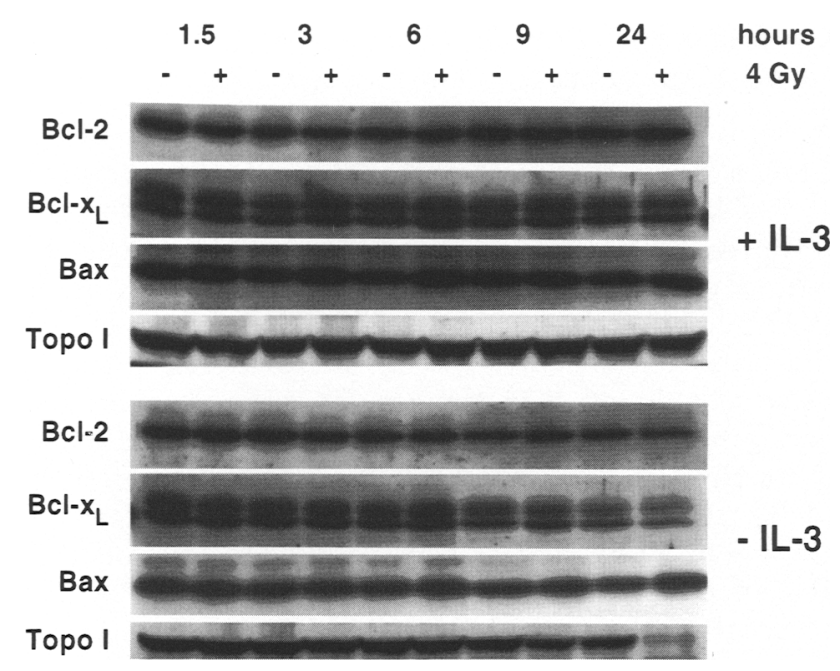

Figure 4. Bcl-2, Bcl- $\mathrm{x}_{\mathrm{L}}$, and $\mathrm{Bax}$ protein levels do not change before IR-induced apoptosis. Baf-3 cells were irradiated or mock-irradiated in the presence or absence of WEHI 3B-conditioned media and harvested for immunoblot analysis 1.5, 3, 6,9, and $24 \mathrm{hr}$ after IR. Lysates corresponding to equivalent cell number were loaded into each lane, and equal loading was confirmed by fast green staining of membrane and immunoblotting against topoisomerase I. The same lysates were analyzed for each immunoblot.

\section{Growth factor modulation of p53-responsive gene products}

Three different gene products have been identified that are induced in a p53-dependent manner after IR: $\mathrm{p} 21^{\mathrm{WAF} 1 / \mathrm{CIP} 1}$, gadd45, and mdm2. p21 $1^{\mathrm{WAF} 1 / \mathrm{CIP} 1}$ has been implicated in mediating the $G_{1}$ cell cycle checkpoint because of its ability to associate with and inhibit $G_{1}$ cyclin/cyclin-dependnet kinase 2 (cdk2) complexes (ElDeiry et al. 1993, 1994; Harper et al. 1993; Xiong et al. 1993; Dulic et al. 1994). In addition, p21 WAF1/CIP1 has been shown to bind directly to proliferating cell nuclear antigen (PCNA) and inhibit PCNA-dependent DNA replication in vitro (Flores-Rozas et al. 1994; Waga et al. 1994). Similar to p $21^{\text {WAF1/CIP1 }}$, gadd 45 has been found to bind to PCNA, and in addition it appears to stimulate excision repair in vitro (Smith et al. 1994) and suppress cell growth in transfected cells (Smith et al. 1994; Zhan et al. 1994b). Mdm2 is believed to be involved in a negative feedback loop by inhibiting p53-mediated transactivation (Barak et al. 1993; Wu et al. 1993; Chen et al. 1994). Whether any of these three proteins are involved in IR-induced apoptosis is currently unknown. Therefore, we proceeded to test whether any of these p53-responsive gene products are induced differentially by IR in the presence or absence of growth factor.

Total RNA was isolated from Baf-3 cells at 1, 2, and 4 $\mathrm{hr}$ after exposure to $4 \mathrm{~Gy}$ ionizing radiation in the presence or absence of IL-3 and analyzed by Northern blot hybridization to various cDNA probes. After exposure to IR in the presence of IL-3, the condition under which Baf- 3 cells undergo $G_{1}$ arrest, both $p 21^{\text {WAF1/CIP1 }}$ and
Mdm2 mRNA are induced by IR (Fig. 5A). Interestingly, we failed to see a significant increase in gadd45 levels after IR, although we did observe measurable increases in gadd45 after treatment of Baf-3 cells with the alkylating agent methyl methane sulfonate (MMS) (data not shown). When irradiated in the absence of IL-3, the condition in which Baf-3 cells undergo rapid p53-dependent apoptosis, Mdm2 mRNA levels increased to an equivalent extent as when cells are irradiated in the presence of IL-3. In contrast, significant changes in the levels of
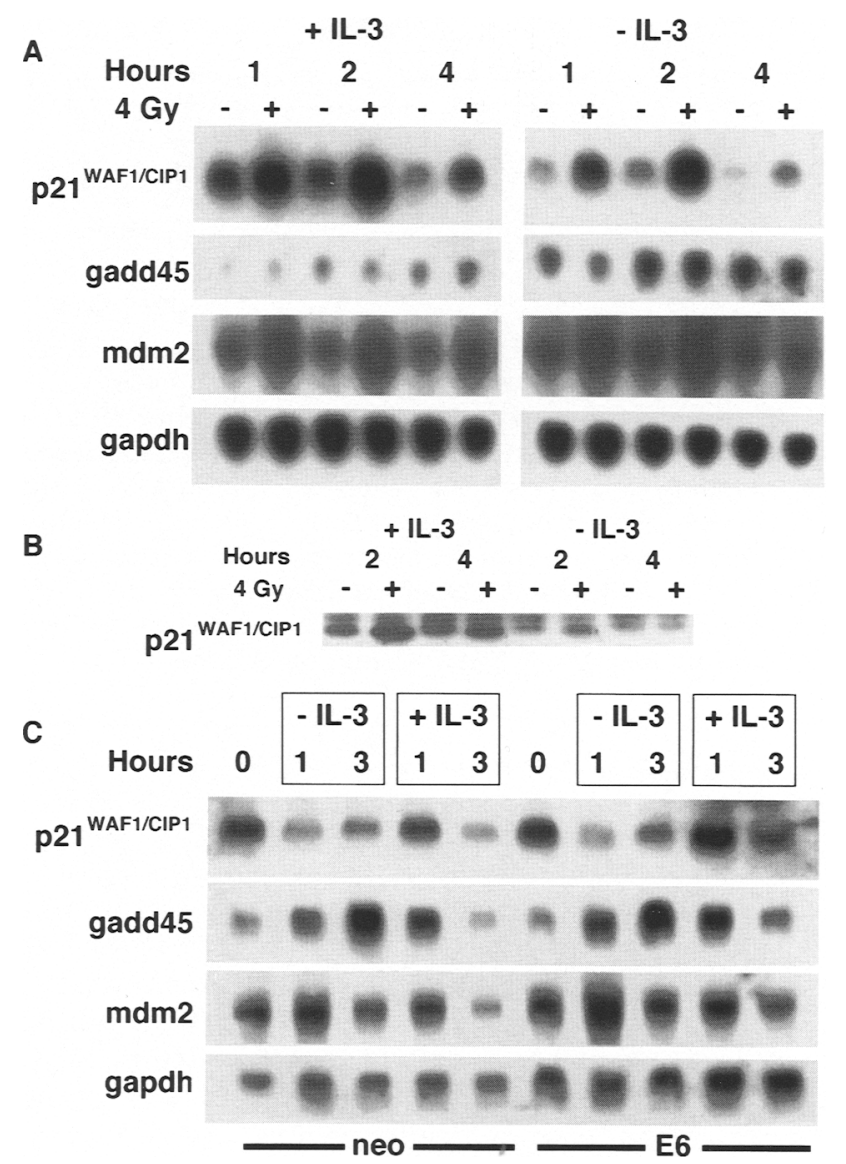

Figure 5. IL-3 modulates the levels of gadd 45 and $\mathrm{p} 21^{\mathrm{WAF} 1 / \mathrm{CIP} 1}$ in both irradiated and nonirradiated cells independently of $\mathrm{p} 53$ function. (A) Total RNA from irradiated or mock-irradiated Baf- 3 cells cultured in the presence or absence of WEHI-conditioned media was isolated from cells at 1,2, and $4 \mathrm{hr}$ after IR and subjected to Northern analysis. The same membrane was stripped and reprobed for each of the mRNA species labeled. $(B)$ Immunoblot analysis of $2_{2} 1^{\text {WAF1/CIP1 }}$ protein levels 2 and $4 \mathrm{hr}$ after irradiation in the presence or absence of WEHI 3B-conditioned media. $(C)$ Neomycin and E6.18 cells were compared for their ability to modulate $\mathrm{p} 21^{\text {WAF1/CIP1 }}$ gadd 45 mRNA levels in response to IL-3 manipulation by Northern blot analysis. Total RNA was isolated from undisturbed cells $(0 \mathrm{hr})$, cells that had been incubated in IL-3-free media for 1 and $3 \mathrm{hr}(13$; - IL-3), or cells that had been starved of IL-3 for $3 \mathrm{hr}$ and then re-exposed to IL-3 $(100 \mathrm{U} / \mathrm{ml}$ of recombinant murine IL-3 for 1 and $3 \mathrm{hr}$; labeled as $13 ;+$ IL-3). Northern hybridization against gapdh is presented as a control for equal loading in both $A$ and $C$. 
$\mathrm{p} 21^{\mathrm{WAF} 1 / \mathrm{CIP} 1}$ and gadd45 were observed in this situation. p $21^{\text {WAF } 1 / C I P 1}$ mRNA levels rapidly decreased after IL-3 withdrawal. IR induced $\mathrm{p} 21^{\mathrm{WAF} 1 / \mathrm{CIP} 1}$ mRNA rapidly as observed in cells cultured with or without IL-3 after IR (Fig. 5A). However, the combined effect of IL-3 withdrawal and IR resulted in 50-75\% less induction of $\mathrm{p} 21^{\mathrm{WAF} 1 / \mathrm{CIP} 1} \mathrm{mRNA}$ as compared to the levels of induction observed in cells irradiated in the presence of IL-3 at $2 \mathrm{hr}$, the time point at which maximal p21 ${ }^{\mathrm{WAF} 1 / \mathrm{CIPl}}$ induction is observed. Consistent with the results obtained through Northern analysis, immunoblot analysis of $\mathrm{p} 21^{\mathrm{WAF} 1 / \mathrm{CIP} 1}$ protein levels confirmed that the induction of $\mathrm{p} 21^{\mathrm{WAF} 1 / \mathrm{CIP} 1}$ protein was substantially less in Baf-3 cells irradiated in the absence of IL-3 as compared with those cells irradiated in the presence of IL-3 (Fig. $5 B$ ). In sharp contrast to $\mathrm{p} 21^{\mathrm{WAF} 1 / \mathrm{CIP} 1}$, gadd 45 mRNA levels did not fall after IL-3 withdrawal but, rather, increased approximately fourfold. Therefore, IL-3 appears to regulate $\mathrm{p} 21^{\mathrm{WAF} 1 / \mathrm{CIP} 1}$ and gadd $45 \mathrm{mRNA}$ levels differentially. These alterations in p21 WAF1/CIP1 and gadd45 expression with growth factor withdrawal occur over a time frame that could account for whether Baf-3 cells undergo $G_{1}$ arrest or apoptosis after exposure to IR.

To demonstrate further that expression of $\mathrm{p} 21^{\mathrm{WAF} 1 / \mathrm{CIP} 1}$ and gadd45 is modulated rapidly by IL- 3 and to determine whether $\mathrm{p} 53$ plays a role in this regulation, Baf-3 cells expressing the E6 protein or neomycin resistance alone were subjected to IL- 3 withdrawal for $\leqslant 3 \mathrm{hr}$, after which purified recombinant murine IL-3 was administered. After IL-3 withdrawal for 1 and $3 \mathrm{hr}, \mathrm{p} 21^{\mathrm{WAF} 1 / \mathrm{CIP} 1}$ levels are down-regulated rapidly in both neomycin and E6-expressing Baf-3 cells (Fig. 5C). After readdition of pure IL-3 to cells that have been starved of IL-3 for $3 \mathrm{hr}$, $\mathrm{p} 21^{\mathrm{WAF} 1 / \mathrm{CIP} 1} \mathrm{mRNA}$ levels returned rapidly to basal levels by $1 \mathrm{hr}$. gadd 45 mRNA levels increased substantially in response to IL-3 withdrawal and rapidly decreased back to basal levels upon readdition of pure IL-3 in both control and E6-expressing cells. There were no consistent changes in Mdm2 mRNA levels in response to growth factor manipulation. Thus, the decreased $\mathrm{p} 21^{\mathrm{WAF} 1 / \mathrm{CIP} 1}$ and increased gadd45 expression upon IL-3 withdrawal were reversed rapidly by readdition of IL-3, and these growth factor-modulated changes were independent of p53 as the E6 transfectants exhibited the same alterations with growth factor withdrawal.

\section{Constitutive expression of oncogenic kinases inhibit} IR-induced apoptosis in cells grown in the absence of $I L-3$

The results presented thus far demonstrate that the presence or absence of growth factor can have a profound impact on whether Baf- 3 cells undergo $G_{1}$ arrest or apoptosis after exposure to IR. Therefore, any oncogenic changes that result in growth factor independence, such as through the constitutive activation of protein kinases involved in growth factor signal transduction /Cleveland et al. 1994; Okuda et al. 1994), may also decrease the susceptibility of such a cell type to undergo apoptosis in response to IR. Hence, we proceeded to examine the ef- fects of enforced expression of activated Src or Raf kinases on $\mathrm{p} 53$-mediated apoptosis in cells grown in the absence of IL-3. Expression vectors were constructed such that v-Src (Johnson et al. 1985) or a truncated form of activated human c-Raf [c-Raf-BXB (Bruder et al. 1992)] was subcloned into a zinc-inducible expression vector containing the sheep metallothionien promoter pMTCB6 + (Hoang et al. 1994). Several stable transfectants were isolated that expressed either v-Src or c-Raf-BXB in a zinc-inducible manner. Results using two $\mathrm{v}$-Src clones and one c-Raf-BXB clone are illustrated here. Clone Src10 constitutively expressed a low basal level of $\mathrm{v}$-Src, and upon addition of zinc, induced v-Src severalfold (Fig. 6A). In contrast, clone Src2 constitutively expressed a relatively high basal level of $\mathrm{v}$-Src as compared with Src10 cells and induced a considerably higher level of $\mathrm{v}$-Src after the addition of zinc (Fig. 6A). Clone BXB7 appeared to express two forms of activated truncated c-Raf (Fig. 6B). These cells constitutively expressed a high level of a protein of the expected size for truncated c-Raf (40-42 kD) (Fig. 6B, labeled BXB). This species was mildly induced by zinc. However, we also noted a smaller species of $\sim 30 \mathrm{kD}$ that was reactive with anti$c$-Raf antibodies and was significantly induced by zinc treatment (Fig. 6B, labeled $\mathrm{BXB}^{\prime}$ ). We currently do not know whether $B X B$ or $B^{\prime} B^{\prime}$ is the active species expressed in these cells.

The individual clones were then evaluated for the level of apoptosis induced by IR in the absence of IL-3. Half of the respective populations were pretreated with zinc for $2 \mathrm{hr}$ before cell washing to remove IL-3. Both populations were then resuspended in IL-3-free medium and those cells that had been pretreated with zinc were again administered the same concentration of zinc, respectively. Cells were then irradiated, incubated for $8 \mathrm{hr}$, and processed for FACScan analysis. A pool of neomycin-resistant Baf-3 cells, which had been transfected with vector alone, served as a control for both the level of apoptosis induced by IR and any negative effects the presence of zinc may have on the apoptotic pathway. Approximately $50 \%$ of the neomycin-resistant cells were positive for apoptosis $8 \mathrm{hr}$ after irradiation in the absence of IL-3, and the presence of zinc did not inhibit the generation of DNA ladders (Fig. 6C). The constitutive level of c-Raf-BXB was somewhat protective to the induction of apoptosis as only $24 \%$ of the cells were $\mathrm{Tdt}^{+} 8 \mathrm{hr}$ after irradiation in the absence of zinc. The same was true for the Src 2 cell line, where only $22 \%$ of the cells were $\mathrm{Tdt}^{+}$after exposure to IR. The relatively low constitutive level of v-Src observed in the Src10 cell line did not appear to be sufficient to significantly protect these cells from IR-induced apoptosis. The addition of zinc to induce either activated c-Raf or v-Src protected all of these cell lines almost completely from apoptosis (Fig. 6C). The induction of v-Src or c-Raf-BXB also appeared to restore the ability of these cells to undergo $G_{1}$ arrest in the absence of IL-3.

Because our previous data raised the possibility that IL-3 withdrawal led to enhanced apoptosis after IR because of down-regulation of $\mathrm{p} 21^{\mathrm{WAF} 1 / \mathrm{CIP1}}$ and up-regula- 
A

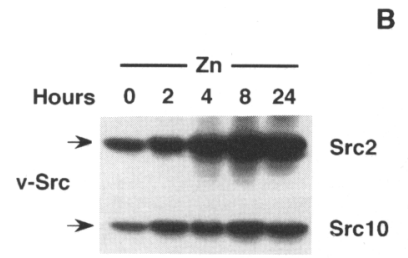

B

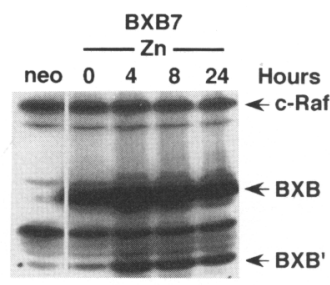

C

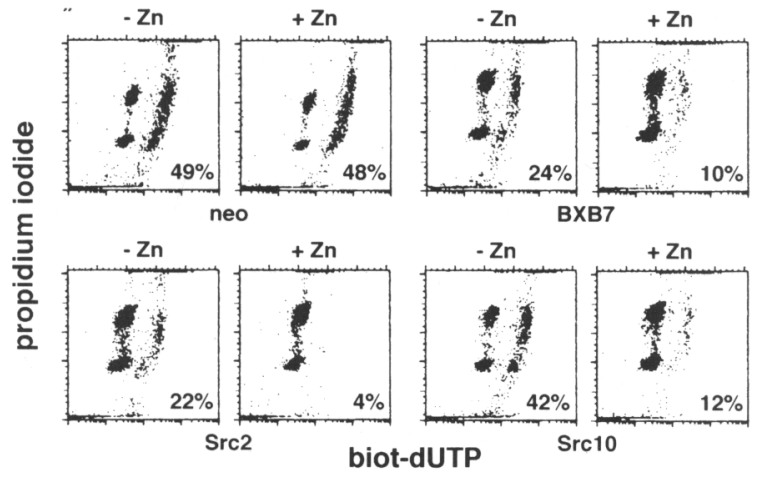

D

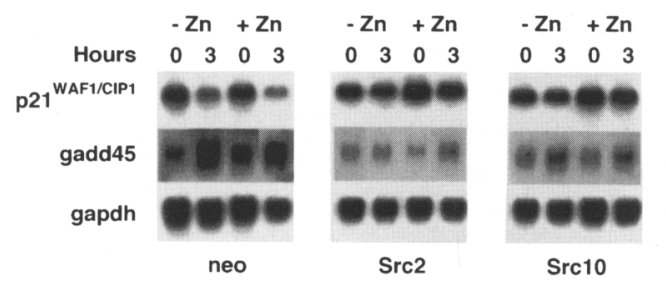

Figure 6. Enforced expression of v-Src or activated c-Raf protects Baf- 3 cells from undergoing IR-induced apoptosis and prevents IL-3 withdrawal-induced modulation of gadd 45 and p21 WAF1/CIP1 mRNA levels. (A) Immunoblot analysis of $\mathrm{v}$-Src levels in clones $\mathrm{Src} 2$ and $\mathrm{Src} 10$ clones after the addition of $75 \mu \mathrm{M}$ $\mathrm{ZnSO}_{4}$ for $0,2,4,8$, and $24 \mathrm{hr}$. (B) Immunoblot analysis for proteins reactive to $\mathrm{c}$-Raf antibodies in neomycin and clone BXB7 cells after the addition of $75 \mu \mathrm{M} \mathrm{ZnSO}$ for $0,4,8$, and 24 $\mathrm{hr}$. Two different proteins were detected that were inducible by zinc: $\mathrm{BXB}$ of $\sim 40-42 \mathrm{kD}$ and $\mathrm{BXB}$ ' of $\sim 30 \mathrm{kD}$. The endogenous c-Raf protein is noted at $\sim 74 \mathrm{kD}$. (C) Neomycin (neo), BXB7, Src2, and Src10 cells were pretreated with $75 \mu \mathrm{M} \mathrm{ZnSO}{ }_{4}$ for $2 \mathrm{hr}$, resuspended in IL-3-free media containing zinc, and irradiated. After $8 \mathrm{hr}$, cells were harvested and processed for FACScan analysis as in Fig. 1. Cells mock-treated with zinc are shown for each cell line. The percentage of cells positive for apoptosis $\left(\mathrm{Tdt}^{+}\right)$are shown in the bottom right-hand corners of each histogram. (D) Neomycin (neo), Src2, and Srcl0 cells were pretreated with $75 \mu \mathrm{M} \mathrm{ZnSO}_{4}$ for $2 \mathrm{hr}$. These cells were then either harvested immediately $(0 \mathrm{hr})$ or subsequently incubated in IL3 -free media for an additional $3 \mathrm{hr}(3)$ in the presence of zinc and then harvested for total RNA isolation and Northern analysis. Cells mock-treated with zinc are shown for each cell line. Northern hybridization against gapdh is presented as a control for equal loading.

tion of gadd45 mRNA levels, we asked whether expression of these activated kinases, which inhibited IR-induced apoptosis, also prevented these changes in $\mathrm{p} 21^{\mathrm{WAF} 1 / \mathrm{CIP} 1}$ and gadd45 expression after growth factor withdrawal. Although $\mathrm{p} 21^{\mathrm{WAF} 1 / \mathrm{CIP} 1}$ expression in con- trol neomycin-resistant cells dropped rapidly with growth factor withdrawal in the presence or absence of zinc, this decrease was inhibited markedly by forced v-Src expression (Fig. 6D). Similarly, the increased gadd45 expression associated with IL-3 withdrawal was blocked by v-Src expression. Thus, the apoptosis versus $\mathrm{G}_{1}$ arrest decision fork again correlated with these changes in $\mathrm{p} 21^{\mathrm{WAF} 1 / \mathrm{CIP} 1}$ and gadd 45 expression.

\section{Discussion}

We used a nonmalignant, growth-factor dependent murine hematopoietic cell line to investigate the factors that determine whether DNA damage induction of p53 protein will result in growth arrest or in rapid programmed cell death. This cell system has the advantages of (1) allowing us to evaluate the entire p53-dependent pathway, starting with induction of endogenous p53 by irradiation; (2) transfectability, allowing evaluation of the effects of altered expression of various gene products on cellular outcome after irradiation; (3) the lack of a requirement for introduction of an exogenous gene such as adenovirus Ela to drive the cell toward apoptosis; and (4) the ability to evaluate the effects of manipulation of this rapid decision fork on long-term cellular outcome, such as clonogenic survival.

Baf- 3 cells that are irradiated in the presence of growth factor IL-3 arrest transiently in the $G_{1}$ and $G_{2} / M$ phases of the cell cycle, whereas Baf-3 cells irradiated in the absence of IL-3 undergo rapid apoptotic cell death. Because a given dose of IR causes both of these outcomes, the simple notion that a low dose of IR leads to growth arrest and a higher dose results in apoptosis is ruled out. The concept that high p53 protein levels can either cause growth arrest or apoptosis, depending on cellular context, was predicted from the original observations of Oren and colleagues that a transfected, overexpressed temperature-sensitive p53 gene caused growth arrest in murine fibroblasts (Michalovitz et al. 1990) at the permissive temperature while resulting in apoptosis in murine leukemia cells (Yonish-Rouach et al. 1991). Because p53-dependent cell cycle arrest is seen in most cell types after irradiation (Kastan et al. 1991, 1992; Kuerbitz et al. 1992) and loss of p53 function and the $G_{1}$ checkpoint in such cells does not alter markedly clonogenic survival (Slichenmyer et al. 1993), whereas p53-dependent apoptosis is evident in irradiated thymocytes (Clarke et al. 1993; Lotem and Sachs 1993; Lowe et al. 1993) (but where clonogenic survival could not be assessed), we suggested that cellular outcome after irradiation of cells with wild-type p53 was modulated by other cellular factors (Slichenmyer et al. 1993). These factors are likely to be determined by the differentiated program of the particular cell type; for example, it may not be desirable for epithelial-derived cells to die upon exposure to DNAdamaging agents as they may incur DNA damage frequently. Data from a number of systems in recent years have solidified the concept that growth factor stimulation can increase tissue cell number by preventing cell death, rather than by driving cellular proliferation 
(Williams et al. 1990). In the experimental system studied here, we extend this concept to demonstrate and evaluate how cytokines can also act as survival signals in the cellular response to DNA damage.

\section{Apoptosis modulation, p21 ${ }^{\text {WAF1/CIP1 }}$, and gadd45}

A number of candidate macromolecules which might be responsible for this decision fork in irradiated cells were evaluated. The lack of significant changes in the levels of the antiapoptotic gene products, $\mathrm{Bcl}-2$ and $\mathrm{Bcl}-\mathrm{x}_{\mathrm{L}}$, or the apoptotic gene product, Bax, in irradiated Baf-3 cells associated with growth factor withdrawal suggests that modulation of the levels of these proteins is not responsible for dictating cellular outcome after p53 induction by irradiation. It is recognized that alterations in activity, rather than levels, of one of these proteins cannot be ruled out at this time. Similarly, differential induction of p53 did not seem to be responsible for determining cellular outcome in the two settings.

Intriguingly, however, growth factor withdrawal led to a rapid decrease in the levels of $\mathrm{p} 21^{\mathrm{WAF} 1 / \mathrm{CIP} 1}$ expression. Although IR and p53 induction still caused an increase in $\mathrm{p} 21^{\mathrm{WAF} 1 / \mathrm{CIP} 1}$ levels in the absence of IL-3, the absolute levels of $\mathrm{p} 21^{\mathrm{WAF} 1 / \mathrm{CIP} 1}$ in the irradiated cells without IL-3 appeared to be significantly less than the levels in irradiated cells with IL-3. It has been suggested recently that $\mathrm{p} 21^{\mathrm{WAF} 1 / \mathrm{CIP1}}$ inhibition of cyclin/cdk activation is dependent on the absolute levels of $\mathrm{p} 21^{\mathrm{WAF1} / \mathrm{CIP1}}$ protein (Zhang et al. 1994). Thus, lower absolute levels of $\mathrm{p} 21^{\mathrm{WAF} 1 / \mathrm{CIP1}}$ in the irradiated cells in the absence of IL-3 could explain the observation that despite increases in p53 and increases in p21 WAF1/CIP1, these cells fail to arrest adequately at the $G_{1}$ checkpoint, enter S-phase, and undergo apoptotic cell death.

This model would suggest that this decision fork may be determined, at least in part, by the modulation of p21 ${ }^{\mathrm{WAF} 1 / \mathrm{CIP1}}$ protein levels by cytokines. Modulation of p21 WAF1/CIP1 expression by IL-3 withdrawal is independent of p53, as the clones expressing HPV-16 E6 also exhibited decreases in $\mathrm{p} 21^{\mathrm{WAF} 1 / \mathrm{CIP} 1}$ expression upon IL-3 withdrawal. This observation is consistent with the recent demonstration that serum stimulation of growtharrested cells results in p53-independent inceases in p21 $1^{\text {WAF1/CIP1 }}$ expression (Michieli et al. 1994). This scenario would also be consistent with the model proposed recently by $\mathrm{Wu}$ and Levine (1994) that simultaneous overexpression of p53 and E2F-1 results in apoptotic cell death. In our cell sytem, irradiation of the IL-3-deprived cells results in increased p53 expression but with levels of $\mathrm{p} 21^{\mathrm{WAF} 1 / \mathrm{CIP1}}$ that may be inadequate to inhibit activation of cyclin/cdk complexes and thus fail to block phosphorylation of $\mathrm{Rb}$ protein, resulting in the release of E2F-1 in cells that have increased levels of $\mathrm{p} 53$ protein. If decreased levels of $\mathrm{p} 21^{\mathrm{WAF} 1 / \mathrm{CIP} 1}$ actually result in increased tendency to apoptosis, as this model would predict, this could explain why $21^{\text {WAF1/CIP1 }}$ is mutated so rarely in human tumors: Mutation and inactivation of p2 $1^{\mathrm{WAF} 1 / \mathrm{CIP} 1}$ in cells with wild-type p53 would increase markedly the tendency of a cell to undergo apoptosis and, therefore, would not be selected for during tumorigenesis. Once a cell mutates p53, there might be little advantage for a tumor cell to mutate $\mathrm{p} 21^{\mathrm{WAF} 1 / \mathrm{CIP} 1}$. Similarly, it might predict difficulty in the construction of a "p21-knockout" mouse.

gadd45 expression also changed rapidly upon growth factor withdrawal, but in contrast to $\mathrm{p} 21^{\mathrm{WAF} 1 / \mathrm{CIP} 1}$, in creased levels of expression were noted. This modulation was also independent of $\mathrm{p} 53$ function and represents one of the first differences between modulation of the expression of $\mathrm{p} 21^{\mathrm{WAF} 1 / \mathrm{CIP} 1}$ and gadd 45 by a particular stimulus. If the change in gadd45 expression was functionally significant, this would seem to implicate increased expression of gadd 45 in the induction of apoptotic cell death and might be consistent with the observation that virtually all types of DNA-damaging agents induce gadd45 expression (Fornace 1992). Transfection of gadd45 into tumor cells results in decreased clonogenicity (Zhan et al. 1994b); however, this could result from either inhibition of cellular proliferation or increased cell death. Unfortunately, the growth-suppressive effects of both gadd 45 and $\mathrm{p} 21^{\mathrm{WAF} / \mathrm{CIP} 1}$ have made it difficult to obtain cells with stably altered levels of expression, even when these genes were introduced into cells under the control of an inducible promoter. Until levels of gadd45 and $\mathrm{p} 21^{\mathrm{WAF} 1 / \mathrm{CIP} 1}$ expression have been manipulated successfully, neither of these potential models can be considered adequately tested. It is also feasible that simultaneous modulation of both gene products is required for the apoptosis end point in these cells and, thus, manipulation of one gene at a time would not be sufficient to alter this response pathway. It is intriguing that both $\mathrm{p} 21^{\mathrm{WAF} 1 / \mathrm{CIP1}}$ (Waga et al. 1994) and gadd45 (Smith et al. 1994) proteins appear to bind to PCNA; thus, simultaneous decreases in $\mathrm{p} 21^{\mathrm{WAF} 1 / \mathrm{CIP1}}$ and increases in gadd 45 expression upon IL-3 withdrawal could work together through PCNA in altering cellular fate.

\section{Signal transduction: effects of Src and Raf on apoptosis}

The ability of growth factor stimulation to enhance cell survival after DNA damage has also been demonstrated in other cell systems (Neta and Oppenheim 1991; Leigh et al. 1993; Waddick and Uckun 1993; Fuks et al. 1994; Haimovitz-Friedman et al. 1994), and serum stimulation prevents or reduces the cell death caused by overexpressed c-myc (Evan et al. 1992) and adenovirus E1a (Lowe and Ruley 1993). These observations in conjunction with ours made it natural to investigate the ability of gene products that participate in growth-related signal transduction pathways to affect cellular outcome after p53 induction by DNA damage. Inducible overexpression of either v-Src or activated c-Raf was able to block the irradiation-induced apoptosis normally seen in IL-3deprived Baf- 3 cells and restored the $G_{1}$ arrest in the irradiated cells despite the absence of IL-3. Both of these gene products also induced $\mathrm{p} 21^{\mathrm{WAF} 1 / \mathrm{CIP1}}$ and inhibited gadd45 expression similar to IL-3 treatment. Because both Src and Raf have been implicated in controlling 
$\mathrm{NF} \kappa \mathrm{B} / \mathrm{I}_{\kappa} \mathrm{B}$ modulation of transcription (Koong et al. 1994), this could be a natural signaling pathway to implicate in this system.

A link between increased c-Raf kinase activity and radio resistance has been suggested previously (Chang et al. 1987; Kasid et al. 1989). Our model system now suggests that this observation may be attributable to an inhibition of p53-mediated apoptotic cell death after irradiation. Because many tumor cells may have alterations in expression of many gene products in such signal transduction pathways (e.g., Src, Raf, Ras), they may have inherent relative insensitivity to DNA-damaging agents on this basis alone, even if wild-type p53 is present. Thus, activation of these oncogenes would have a different phenotype than activation of oncogenes such as c-myc, adenovirus E1a, or HPV E7, where overexpression of the latter group would result in increased tendencies to apoptosis and require mutations in $\mathrm{p} 53$ to abrogate the apoptosis phenotype (Evan et al. 1992; Debbas and White 1993; White et al. 1994). This requirement has been proposed as the reason that so many tumor cells mutate p53 during multistep tumorigenesis (Lowe et al. 1994; Symonds et al. 1994). Our data further suggest the concept that oncogenes could be divided into two classes, one group that enhances apoptotic tendencies and one group that inhibits them. It is conceivable that whether and when during tumorigenesis p53 becomes mutated could be dictated by which class of mutations have occurred already. For example, tumor types that rarely mutate p53, such as lymphoid leukemias, germ cell tumors, and neuroblastomas, may be able to proceed through the tumorigenesis process without mutating $\mathrm{p} 53$ because they resist apoptosis by other mechanisms, such as activation of this other class of oncogenes or constitutive stimulation of growth factor pathways by paracrine or autocrine mechanisms. Perhaps the observation that Burkitt's lymphoma is unusual among hematopoietic malignancies in having a reasonable frequency of p53 mutations results from overexpression of c-myc (Milner et al. 1993). Increased apoptosis tendencies attributable to c-myc overexpression may invoke a greater need to mutate p53 relative to other hematopoietic tumors. Those tumors that retain wild-type p 53 may be more curable with current antineoplastic therapies than tumors that resist apoptosis by mutating $\mathrm{p} 53$ or overexpressing $\mathrm{Bcl}-2$, because metabolic manipulations could still result in apoptotic cell death after DNA damage.

These observations suggest that inhibition of such signal transduction pathways at the time of exposure of cells to DNA-damaging antineoplastic agents could increase the sensitivity of cells (with wild-type p53) to these agents. Transient removal of IL-3 only at the time of irradiation was sufficient to result in decreased clonogenic survival of the Baf-3 cells. Thus, the cytokine signal transduction pathway becomes a reasonable rational target to try to improve efficacy of chemotherapy and radiotherapy as only brief inhibitions of the pathway would be required at the time of exposure. Theoretically selective cytotoxicity could also be achieved by appropriate use of cytokines or their surrogates to protect spe- cific normal tissues. Further investigations of this and other systems amenable to manipulation of apoptosis end points should continue to provide new insights into potential mechanisms to increase selective cytotoxicity of tumor cells.

\section{Materials and methods}

\section{Expression vectors and plasmid constructions}

pCMVE6 contains the HPV-16 E6 gene subcloned into pCMVneobam downstream of the cytomegalovirus promoter (Kessis et al. 1993) (obtained from K.R. Cho and L. Hedrick, Johns Hopkins Univeresity, Baltimore, MD). For the construction of pMTv-Src, plasmid pMv-Src (Johnson et al. 1985) was cleaved with NcoI and the 5' overhang was filled in with DNA polymerase. Plasmid DNA was then digested with $X b a I$, and the 1680 -kb v-Src fragment was subcloned into the $E c o R V$ and $X b a \mathrm{I}$ sites of plasmid MT-CB6 + (provided by F. Rauscher, Wistar Institute, Philadelphia, PA) downstream of a sheep metallothionein promoter. For the construction of pMTBXB, RSV-Raf-BXB (Bruder et al. 1992) (obtained from John L. Cleveland, St. Jude's Children research Hospital, Memphis, TN| was cleaved with $C l a I$ and $X b a I$ and the resulting DNA fragment, encoding the truncated form of activated c-Raf cDNA, was subcloned into the $\mathrm{ClaI}$ and $\mathrm{XbaI}$ sites of MT-CB6+. For DNA transfections, plasmid DNAs were linearized after digestion with ScaI (pMTv-Src and $\mathrm{pMTBXB}$ ) and $\mathrm{XmnI}$ (pCMVE6). All three expression vectors contain a neomycin-resistance marker gene.

\section{Cell culture and DNA transfections}

Baf-3 (Palacios and Steinmetz 1985) cells were cultured in RPMI (GIBCO Life Sciences) containing 10\% fetal bovine serum (Atlanta Biologicals) and 10\% WEHI 3B-conditioned medium as a source of IL-3. In some experiments, Baf-3 cells were cultured in the presence of purified recombinant murine IL-3 (GIBCO Life Sciences). Before irradiation, exponentially growing cells were washed twice in serum-free RPMI and resuspended in media either containing or lacking IL-3. Clonogenicity was measured 6 hr after irradiation by seeding known concentrations of cells by limiting dilution into 96-well plates in media containing IL-3. Cells were seeded under conditions such that growth in a well originated from a single cell. After 8 days, plates were scored for colonies and plating efficiency was calculated by dividing the number of wells containing growth by the total number of cells seeded. The surviving fraction was then calculated by normalizing the plating efficiency of treated cells to that observed for nonirradiated control cells that had been incubated either in the presence or absence of IL-3, respectively, during the course of the experiment.

To generate stable DNA transfectants, $10^{7}$ cells were resuspended in $1 \mathrm{ml}$ of PBS plus $15 \mu \mathrm{g}$ of linearized plasmid DNA and electroporated (1.2 kV, $25 \mu \mathrm{FD}$; Bio-Rad Gene Pulser). Cells were then allowed to recover for $24-48 \mathrm{hr}$ and stable transfectants were selected for neomycin resistance with $0.5 \mathrm{mg} / \mathrm{ml}$ of geneticin (GIBCO Life Sciences). Individual clones were isolated by limiting dilution of a polyclonal neomycin-resistant population into 96-well plates and then screened for the expression of the transfected gene of interest by immunoblot analysis. In the case of pCMVE6 transfectants, clones were screened for the absence of p53 induction by IR. pMTv-Src and pMTBXB transfectants were screened for $\mathrm{v}$-Src, and truncated human c-Raf expression induced by $\mathrm{Zn}^{+2}$. A concentration of $75 \mu \mathrm{M}$ 
$\mathrm{ZnSO}_{4}$ was used to induce the expression of v-Src and c-Raf$\mathrm{BXB}$ in all experiments indicated.

\section{Immunoblot analysis}

Cells were harvested, counted, and solubilized in Laemmli sample buffer as described previously (Kastan et al. 1992). Cell extracts corresponding to equivalent cell numbers were loaded into each lane, and total cellular proteins were then separated by SDS-PAGE. After wet electrotransfer onto nitrocellulose membranes, equivalent loading was confirmed by fast green staining as described previously (Kastan et al. 1992). Immunoblots with antibodies to 553 (a mixture of PAb421 and PAb420; Oncogene Science), to human c-Raf $(\mathrm{C}-20)$ and murine p21 WAF1/CIP1 (M-19) (Santa Cruz Biotechnology), and to topoisomerase I (Topogen) were used. Antibodies to v-Src (monoclonal antibody 327) were purified from hybridoma cells provided by Joan Brugge (Ariad, Cambridge, MA). Antibodies to murine Bcl-2 and Bax were provided by John Reed (LaJolla Cancer Research Foundation, CA), and antibodies to murine Bcl-x were provided by Craig Thompson (University of Chicago, IL). After primary antibody staining, blots were stained with horseradish peroxidase-conjugated secondary antibodies and autoradiographed using enhanced chemiluminescence (Amersham Life Sciences).

\section{Northern analysis}

Total RNA was purified from Baf-3 cells using the single-step acid guanidinium thiocyanate-phenol-chloroform extraction method (Chomczynski and Sacchi 1987). Equal amounts of total RNA were electrophoresed on formaldehyde-agarose gels and transferred onto Nytran membranes (Schleicher \& Schuell). cDNA probes were random prime labeled with $\left[{ }^{32} \mathrm{P}\right] \mathrm{dCTP}$ according to manufacturer's directions (Boehringer Mannheim) and hybridized to immobilized RNA for $2 \mathrm{hr}$ in Rapid-hyb buffer (Amersham Life Science) at $65^{\circ} \mathrm{C}$ for p21 WAFI/CIPI, $\mathrm{Mdm} 2$, and gapdh, and at $62^{\circ} \mathrm{C}$ for gadd45. Blots were first washed at room temperature with $2 \times$ SSC, $0.1 \%$ SDS, and then at $65^{\circ} \mathrm{C}$ with $0.2 \times \mathrm{SSC}, 0.1 \%$ SDS (p2 $1^{\mathrm{WAF} 1 / \mathrm{CIP1}}, \mathrm{Mdm} 2$, and gapdh), or at $62^{\circ} \mathrm{C}$ with $0.5 \times$ SSC, $0.1 \%$ SDS (gadd 45 ). Northern blots were quantitated by PhosphorImager analysis.

For cDNA probes, a $0.8-\mathrm{kb}$ murine $\mathrm{p} 21^{\mathrm{WAF} 1 / \mathrm{CIP} 1} \mathrm{cDNA}$ fragment was excised from the vector pCMW35 (provided by Bert Vogelstein, Johns Hopkins University, Baltimore, MD/ after digestion with EcoRI; a 1.2-kb Chinese hamster ovary gadd 45 cDNA fragment was excised from the vector pXR45m (Papathanasiou et al. 1991) (provided by Al Fornace, National Institutes of Health) after digestion with KpnI and SacI; a 3-kb murine mdm 2 cDNA fragment was excised from vector B101 (provided by Donna L. George, University of Pennsylvania) after digestion with EcoRI; and a 780-bp human gapdh cDNA fragment was excised from vector pBS-GAP-PX (provided by Paula Vertino, Johns Hopkins) after digestion with $\mathrm{XbaI}$ and PstI.

\section{Flow cytometry}

Baf-3 cells were analyzed for both cell cycle positions and apoptosis using a Tdt/PI assay (Gorczyca et al. 1993). Briefly, cells were first fixed in PBS containing 1\% formaldehyde to immobilize apoptotic DNA fragments and then fixed in $70 \%$ methanol to permeabilize cells. Apoptotic DNA fragments were then end-labeled in situ with biotinylated dUTP (Boeringer Mannheim) by terminal transferase and then stained with fluoresceinated avidin (Boeringer Mannheim). Cells were then counterstained with $25 \mu \mathrm{g} / \mathrm{ml}$ of propidium iodide (Sigma) containing
$20 \mu \mathrm{g} / \mathrm{ml}$ of RNase A (Sigma) and analyzed by flow cytometry on a FACScan flow cytometer (Becton Dickinson). A total of 9000 events were collected, and ungated data are presented in all figures shown.

\section{Acknowledgments}

We thank John Cleveland, John Reed, Albert J. Fornace, Jr., Kathleen Cho, Lora Hedrick, Bert Vogelstein, Frank Rauscher, Craig Thompson, Joan Brugge, Paula Vertino, and Donna George for generously providing many of the probes and antibodies used in these studies. We thank Moshe Oren for helpful discussions and Tim Lansing and Amanda Lee for excellent technical assistance. This work was supported in part by grants from the National Institutes of Health (CA61949, ES05777, and T32CA60441) and the Glaxo Research Institute. M.B.K. is The Steven Birnbaum Scholar of the Leukemia Society of America.

The publication costs of this article were defrayed in part by payment of page charges. This article must therefore be hereby marked "advertisement" in accordance with 18 USC section 1734 solely to indicate this fact.

\section{References}

Barak, Y., T. Juven, R. Haffner, and M. Oren. 1993. mdm2 expression is induced by wild type p53 activity. EMBO $J$. 12: 461-468.

Boise, L.H., M. Gonzalez-Garcia, C.E. Postema, L. Ding, T. Lindsten, L.A. Turka, X. Mao, G. Nunez, and C.B. Thompson. 1993. bcl-x, a bcl-2-related gene that functions as a dominant regulator of apoptotic cell death. Cell 74: 597-608.

Bruder, J.T., G. Heidecker, and U.R. Rapp. 1992. Serum-, TPA-, and Ras-induced expression from Ap-1/Ets-driven promoters requires Raf-1 kinase. Genes \& Dev. 6: 545-556.

Chang, E.H., K.F. Pirollo, Z.Q. Zou, H. Cheung, E.L. Lawler, R. Garner, E. White, W.B. Bernstein, J.W. Fraumeni, and W.A. Blattner. 1987. Oncogenes in radioresistant, noncancerous skin fibroblasts from a cancer-prone family. Science 237: 1036-1039.

Chen, C., J.D. Oliner, Q. Zhan, A.J. Fornace Jr., B. Vogelstein, and M.B. Kastan. 1994. Interactions between p53 and MDM2 in a mammalian cell cycle checkpoint pathway. Proc. Natl. Acad. Sci. 91: 2684-2688.

Chomczynski, P. and N. Sacchi. 1987. Single-step method of RNA isolation by acid guanidinium thiocyanate-phenolchloroform extraction. Anal. Biochem. 162: 156-159.

Clarke, A.R., C.A. Purdie, D.J. Harrison, R.G. Morris, C.C. Bird, M.L. Hooper, and A.H. Wylie. 1993. Thymocyte apoptosis induced by p53-dependent and independent pathways. $\mathrm{Na}$ ture 362: 849-852.

Cleveland, J.L., J. Troppmair, G. Packham, D.S. Askew, P. Lloyd, M. Gonzalez-Garcia, G. Nunez, J.N. Ihle, and U.R. Rapp. 1994. v-raf suppresses apoptosis and promotes growth of interleukin-3-dependent myeloid cells. Oncogene 9: 2217-2226.

Collins, M.K.L., J. Marvel, P. Malde, and A. Lopez-Rivas. 1992. Interleukin 3 protects murine bone marrow cells from apoptosis induced by DNA damaging agents. I. Exp. Med. 176: 1043-1051.

Debbas, M. and E. White. 1993. Wild-type p53 mediates apoptosis by ElA, which is inhibited by ElB. Genes \& Dev. 7: 546-554.

Demers, G.W., S.A. Foster, C.L. Halbert, and D.A. Galloway. 1994. Growth arrest by induction of p53 in DNA damaged keratinocytes is bypassed by human papillomavirus $16 \mathrm{E} 7$. 
Proc. Natl. Acad. Sci. 91: 4382-4386.

Dulic, V., W.K. Kaufmann, S.J. Wilson, T.D. Tlsty, E. Lees, W. Harper, S.J. Elledge, and S.I. Reed. 1994. p53-Dependent inhibition of cyclin-dependent kinase activities in human fibroblasts during radiation-induced Gl arrest. Cell 76: 10131023.

El-Deiry, W.S., T. Tokino, V.E. Velculescu, D.B. Levy, R. Parsons, J.M. Trent, D. Lin, W.E. Mercer, K.W. Kinzler, and B. Vogelstein. 1993. WAF1, a potential mediator of p53 tumor suppression. Cell 75: 817-825.

EI-Deiry, W.S., J.W. Harper, P.M. O'Conner, V.E. Velculescu, C.E. Canman, J. Jackman, J.A. Pietenpol, M. Burrell, D.E. Hill, Y. Wang, K.G. Wiman, W.E. Mercer, M.B. Kastan, K.W. Kohn, S.J. Elledge, K.W. Kinzler, and B. Vogelstein. 1994. WAFI/CIPI is induced in p53-mediated $\mathrm{G}_{1}$ arrest and apoptosis. Cancer Res. 54: 1169-1174.

Evan, G.I., A.H. Wyllie, C.S. Gilbert, T.D. Littlewood, H. Land, M. Brooks, C.M. Waters, L.Z. Penn, and D.C. Hancock. 1992. Induction of apoptosis in fibroblasts by c-myc protein. Cell 69: 119-128.

Flores-Rozas, H., Z. Kelman, F.B. Dean, Z. Pan, J.W. Harper, S.J. Elledge, M. O'Donnell, and J. Hurwitz. 1994. Cdk-interacting protein 1 directly binds with proliferating cell nuclear antigen and inhibits DNA replication catalyzed by the DNA polymerase $\delta$ holoenzyme. Proc. Natl. Acad. Sci. 91: 86558659.

Fornace, A.J. Jr. 1992. Mammalian genes induced by radiation: Activation of genes associated with growth control. Annu. Rev. Genet. 26: 507-526.

Fuks, Z., R.S. Persaud, A. Alfieri, M. McLoughlin, D. Ehleiter, J.L. Schwartz, A.P. Seddon, C. Cordon-Cardo, and A. Haimovitz-Friedman. 1994. Basic fibroblast growth factor protects endothelial cells against radiation-induced programmed cell death in vitro and in vivo. Cancer Res. 54: 2582-2590.

Gorczyca, W., J. Gong, and Z. Darzynkiewics. 1993. Detection of DNA strand breaks in individual apoptotic cells by the in situ terminal deoxynucleotidyl transferase and nick translation assays. Cancer Res. 53: 1945-1951.

Haimovitz-Friedman, A., N. Balaban, M. McLoughlin, D. Ehleiter, J. Michaeli, I. Vlodavsky, and Z. Fuks. 1994. Protein kinase $\mathrm{C}$ mediates basic fibroblast growth factor protection of endothelial cells against radiation-induced apoptosis. Cancer Res. 54: 2591-2597.

Harper, J.W., G.R. Adami, N. Wei, K. Keyomarsi, and S.J. Elledge. 1993. The p21 Cdk-interacting protein Cipl is a potent inhibitor of $\mathrm{Gl}$ cyclin-dependent kinases. Cell 75: 805-816.

Hoang, A.T., K.J. Cohen, J.F. Barrett, D.A. Bergstrom, and H.V. Hang. 1994. Participation of cyclin A in Myc-induced apoptosis. Proc. NatI. Acad. Sci. 91: 6875-6879.

Johnson, P.J., P.M. Coussens, A.V. Danko, and D. Shalloway. 1985. Overexpressed pp $60^{\text {c.src }}$ can induce focus formation without complete transformation of NIH 3T3 Cells. Mol. Cell. Biol. 5: 1073-1083.

Kasid, U., A. Pfeifer, T. Brennan, M. Beckett, R.R. Weichselbaum, A. Dritschilo, and G.E. Mark. 1989. Effect of antisense c-raf- 1 on tumorigenicity and radiation sensitivity of a human squamous carcinoma. Science 243: 1354-1356.

Kastan, M.B., O. Onyekwere, D. Sidransky, B. Vogelstein, and R.W. Craig. 1991. Participation of p53 protein in the cellular response to DNA damage. Cancer Res. 51: 6304-6311.

Kastan, M.B., Q. Zhan, W.S. El-Deiry, F. Carrier, T. Jacks, W.V. Walsh, B.S. Plunkett, B. Vogelstein, and A.J. Fornace Jr. 1992. A mammalian cell cycle checkpoint pathway utilizing p53 and GADD45 is defective in ataxia-telangiectasia. Cell 71: 587-597.
Kessis, T.D., R.J. Slebos, W.G. Nelson, M.B. Kastan, B.S. Plunkett, S.M. Han, A.T. Lorincz, L. Hedrick, and K.R. Cho. 1993. Human papillomavirus 16 E6 expression disrupts the p53-mediated cellular response to DNA damage. Proc. Natl. Acad. Sci. 90: 3988-3992.

Koong, A.C., E.Y. Chen, N.F. Mivechi, N.C. Denko, P. Stambrook, and A.J. Giaccia. 1994. Hypoxic activation of nuclear factor- $\mathrm{kB}$ is mediated by a Ras and Raf signaling pathway and does not involve MAP kinase (ERK1 or ERK2). Cancer Res. 54: 5273-5279.

Kuerbitz, S.J., B.S. Plunkett, W.V. Walsh, and M.B. Kastan. 1992. Wild-type p53 is a cell cycle checkpoint determinant following irradiation. Proc. Natl. Acad. Sci. 89: 7491-7495.

Leigh, B.R., S.L. Hancock, and S.J. Knox. 1993. The effect of stem cell factor on irradiated human bone marrow. Cancer Res. 53: 3857-3859.

Lotem, J. and L. Sachs. 1993. Hematopoietic cells from mice deficient in wild-type p53 are more resistant to induction of apoptosis by some agents. Blood 82: 1092-1096.

Lowe, S.W. and H.E. Ruley. 1993. Stabilization of the p53 tumor suppressor is induced by adenovirus $5 \mathrm{E} 1 \mathrm{~A}$ and accompanies apoptosis. Genes \& Dev. 7: 535-545.

Lowe, S.W., S.W. Schmitt, S.W. Smith, B.A. Osborne, and T. Jacks. 1993. p53 is required for radiation-induced apoptosis in mouse thymocytes. Nature 362: 847-849.

Lowe, S.W., T. Jacks, D.E. Housman, and H.E. Ruley. 1994. Abrogation of oncogene-associated apoptosis allows transformation of p53-deficient cells. Proc. Natl. Acad. Sci. 91: 2026-2030.

Michalovitz, D., O. Halevy, and M. Oren. 1990. Conditional inhibition of transformation and of cell proliferation by a temperature-sensitive mutant of p53. Cell 62: 671-680.

Michieli, P., M. Chedid, D. Lin, J.H. Pierce, W.E. Mercer, and D. Givol. 1994. Induction of WAF1/CIP1 by a p53-independent pathway. Cancer Res. 54: 3391-3395.

Milner, A.E., R.J.A. Grand, C.M. Waters, and C.D. Gregory. 1993. Apoptosis in Burkitt lymphoma cells is driven by c-myc. Oncogene 8: 3385-3391.

Miyashita, T., S. Krajewski, M. Krajewska, H.G. Wang, H.K. Lin, D.A. Liebermann, B. Hoffman, and J.C. Reed. 1994. Tumor suppressor p53 is a regulator of $b c l-2$ and bax gene expression in vitro and in vivo. Oncogene 9: 1799-1805.

Neta, R. and J.J. Oppenheim. 1991. Radioprotection with cytokines-learning from nature to cope with radiation damage. Cancer Cells 3: 391-396.

Nunez, G., L. London, D. Hockenberry, M. Alexander, J.P. McKearn, and S.J. Korsmeyer. 1990. Deregulated Bcl-2 gene expression selectively prolongs survival of growth factor-deprived hemopoietic cell lines. I. Immunol. 144: 3602-3610.

Okuda, K., U. Matulonis, R. Salgia, Y. Kanakura, B. Druker, and J.D. Griffin. 1994. Factor independence of human myeloid leukemia cell lines is associated with increased phosphorylation of the proto-oncogene Raf-1. Exp. Hematol. 22: 11111117.

Otani, H., M. Erdos, and W.J. Leonard. 1993. Tyrosine kinase(s) regulate apoptosis and bcl-2 expression in a growth factordependent cell line. J. Biol. Chem. 268: 22733-22736.

Palacios, R. and M. Steinmetz. 1985. IL-3-dependent mouse clones that express B-220 surface antigen, contain Ig genes in germ-line configuration, and generate B lymphocytes in vivo. Cell 41: 727-734.

Papathanasiou, M.A., N.C.K. Kerr, J.H. Robbins, O.W. Mcbride, I. Alamo Jr., S. Barrett, I.D. Hickson, and A.J. Fornace Jr. 1991. Induction by ionizing radiation of the GADD45 gene in cultured human cells: Lack of mediation by protein kinase C. Mol. Cell. Biol. 11: 1009-1016. 
Scheffner, M., B.A. Werness, J.M. Huibregtse, A.J. Levine, and P.M. Howley. 1990. The E6 oncoprotein encoded by human papillomavirus types 16 and 18 promotes the degradation of p53. Cell 63: 1129-1136.

Selvakumaran, M., H. Lin, T. Miyashita, H.G. Wang, S. Krajewski, J.C. Reed, B. Hoffman, and D. Liebermann. 1994. Immediate early up-regulation of bax expression by p53 but not TGF 31 : A paradigm for distinct apoptotic pathways. Oncogene 9: 1791-1798.

Slebos, R.J.C., M.H. Lee, B.S. Plunkett, T.D. Kessis, B.O. Williams, T. Jacks, L. Hedrick, M.B. Kastan, and K.R. Cho. 1994. p53-dependent $G_{1}$ arrest involves pRB-related proteins and is disrupted by the human papillomavirus 16 E7 oncoprotein. Proc. Natl. Acad. Sci. 91: 5320-5324.

Slichenmyer, W.J., W.G. Nelson, R.J. Slebos, and M.B. Kastan. 1993. Loss of a p53-associated G1 checkpoint does not decrease cell survival following DNA damage. Cancer Res. 53: 4164-4168.

Smith, M.L., I. Chen, I. Bae, C. Chen, T. Gilmer, M.B. Kastan, P.M. O'Connor, and A.J. Fornace. 1994. Interaction of the p53-regulated protein Gadd45 with proliferating cell nuclear antigen. Science 266: 1376-1380.

Symonds, H., L. Krall, L. Remington, M. Saenz-Robles, S. Lowe, T. Jacks, and T. Van Dyke. 1994. p53-Dependent apoptosis suppresses tumor growth and progression in vivo. Cell 78: 703-711.

Waddick, K.G. and F.M. Uckun. 1993. Effects of recombinant interleukin-3 and recombinant interleukin- 6 on radiation survival of normal human bone marrow progenitor cells. $R a$ diat. Oncol. Invest. 1: 34-40.

Waga, S., G.J. Hannon, D. Beach, and B. Stillman. 1994. The p21 inhibitor of cyclin-dependent kinases controls DNA replication by interaction with PCNA. Nature 369: 574-578.

White, A.E., E.M. Livanos, and T.D. Tlsty. 1994. Differential disruption of genomic integrity and cell cycle regulation in normal human fibroblasts by the HPV oncoproteins. Genes \& Dev. 8: 666-677.

Williams, G.T., C.A. Smith, E. Spooncer, T.M. Dexter, and D.R. Taylor. 1990. Haemopoietic colony stimulating factors promote cell survival by suppressing apoptosis. Nature 343: 7679.

Wu, X. and A.J. Levine. 1994. p53 and E2F-1 cooperate to mediate apoptosis. Proc. Natl. Acad. Sci. 91: 3602-3606.

Wu, X., H. Bayle, D. Olson, and A.J. Levine. 1993. The p53mdm-2 autoregulatory feedback loop. Genes \& Dev. 7: 1126-1132.

Xiong, Y., G.J. Hannon, H. Zhang, D. Casso, R. Kobayashi, and D. Beach. 1993. p21 is a universal inhibitor of cyclin kinases. Nature 366: 701-704.

Yonish-Rouach, E., D. Resnitzky, J. Lotem, L. Sachs, A. Kimchi, and M. Oren. 1991. Wild-type p53 induces apoptosis of myeloid leukaemic cells that is inhibited by interleukin-6. $\mathrm{Na}$ ture 352: 345-347.

Zhan, Q., I. Bae, M.B. Kastan, and A.J. Fornace Jr. 1994a. The p53-dependent gamma-ray response of GADD45. Cancer Res. 54: 2755-2760.

Zhan, Q., K.A. Lord, I. Alamo Jr., M.C. Hollander, F. Carrier, D. Ron, K.W. Kohn, B. Hoffman, D.A. Liebermann, and A.J. Fornace Jr. 1994b. The gadd and MyD genes define a novel set of mammalian genes encoding acidic proteins that synergistically suppress cell growth. Mol. Cell. Biol. 14: 23612371.

Zhang, H., G.J. Hannon, and D. Beach. 1994. p21-containing cyclin kinases exist in both active and inactive states. Genes \& Dev. 8: 1750-1758. 


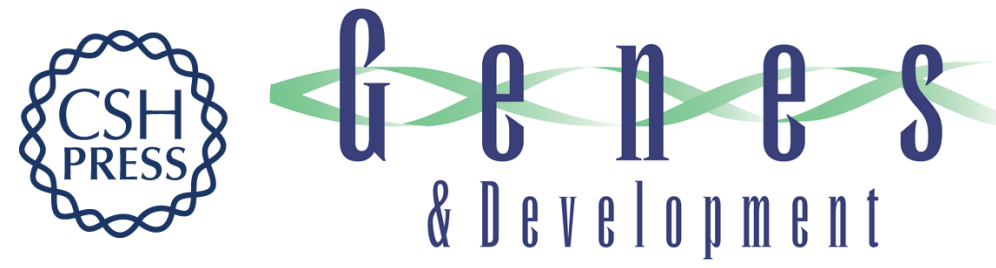

\section{Growth factor modulation of p53-mediated growth arrest versus apoptosis.}

C E Canman, T M Gilmer, S B Coutts, et al.

Genes Dev. 1995, 9:

Access the most recent version at doi:10.1101/gad.9.5.600

References This article cites 61 articles, 35 of which can be accessed free at:

http://genesdev.cshlp.org/content/9/5/600.full.html\#ref-list-1

\section{License}

Email Alerting

Service

Receive free email alerts when new articles cite this article - sign up in the box at the top right corner of the article or click here.

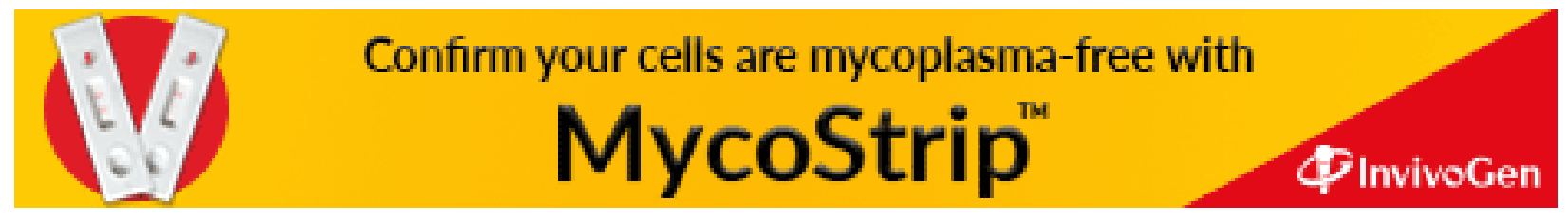

